\title{
THE COAGULATION OF INSOLUBLE AND BASIC PROTEINS FROM RAT SEMINAL VESICLE SECRETION WITH VESICULASE: INFLUENCE OF COLLAGENASE- LIKE PEPTIDASE FROM RAT TESTIS
}

\author{
E. KOREN, E. SGHÖN AND J. LUKAC̈ \\ Laboratory for Experimental Medicine, University of Zagreb, \\ Vinogradska c. 29, 41000 Zagreb, Kugoslavia
}

(Received 4th Fuly 1974)

\begin{abstract}
Summary. Proteins from the secretion of rat seminal vesicles were fractionated to yield (i) insoluble protein, (ii) basic proteins (soluble in the presence of urea) and (iii) neutral plus acidic proteins. The first two are necessary for the formation in vitro of a coagulum which is very similar to the copulatory plug. Collagenase-like peptidase from rat testis degrades both protein fractions and prevents coagulum formation.
\end{abstract}

\section{INTRODUCTION}

Rat semen is deposited into the female genital tract in the form of a copulatory plug. It remains in the vagina for several hours and is believed to prevent the back-flow of spermatozoa. The release of spermatozoa from this compact mass is a phenomenon that requires explanation.

The coagulation of rat semen is caused by the interaction of the basic protein of the seminal secretion with vesiculase, an enzyme of the coagulating gland (Mann, 1954; Manyai, 1964).

We now give evidence that in addition to basic proteins, insoluble protein from seminal vesicle secretion is necessary for formation of the copulatory plug. The effects of collagenase-like peptidase (CLP) (Koren \& Milković, 1973; Koren, Lukać \& Milković, 1974) on seminal vesicle secretion fractions indispensable for formation of the copulatory plug are presented and a rôle for sperm CLP in the release of spermatozoa from the plug is suggested.

\section{MATERIALS AND METHODS}

Male rats of the Fischer strain, aged 6 to 8 months and weighing 260 to $300 \mathrm{~g}$, were used.

Seminal vesicle secretion was obtained by puncturing the seminal vesicle with a large needle and sucking the contents into a dry syringe.

A solution of purified CLP from rat testis $(0.6$ to $0.8 \mathrm{mg}$ protein $/ \mathrm{ml}, 80$ to 100 units/mg protein) was obtained as described previously (Koren et al., 1974).

Vesiculase from the rat anterior prostate was partially purified and tested 
as described by Gotterer, Ginsberg, Schulman, Banks \& Williams-Ashman (1955).

\section{Fractionation of the rat seminal vesicle secretion}

Seminal vesicle secretion obtained from six seminal vesicles $(1.2$ to $1.5 \mathrm{ml})$

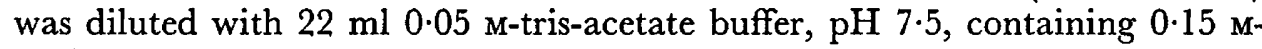
$\mathrm{NaCl}$. The diluted secretion was centrifuged for $20 \mathrm{~min}$ at $1200 \mathrm{~g}$. The clear supernatant fluid (I) was kept and the pellet was washed five times with trisacetate- $\mathrm{NaCl}$, then five times with $2 \mathrm{M}$-urea, and finally with cold acetone. The resulting pellet was dried in air and the powder obtained, i.e. Fraction $A$ $\left(60\right.$ to $70 \mathrm{mg}$ ), was stored in a desiccator. Fluid I was stirred at $0^{\circ} \mathrm{C}$ and ammonium sulphate was added slowly to $40 \%$ saturation. The mixture was centrifuged for $20 \mathrm{~min}$ at $1200 \mathrm{~g}$ to yield a clear fluid (II) and a sediment. The latter was washed five times with tris-acetate- $\mathrm{NaCl}$ buffer and dissolved in the same buffer containing $2 \mathrm{~m}$-urea. In this way, Fraction B (about $1.5 \mathrm{ml}$, $26.4 \mathrm{mg}$ protein $/ \mathrm{ml}$ ) was obtained. Fluid II was treated with ammonium sulphate and the precipitate formed at between 50 and $80 \%$ saturation was collected. It was dissolved in tris-acetate- $\mathrm{NaCl}$ and dialysed at $4{ }^{\circ} \mathrm{C}$ for $24 \mathrm{hr}$ against the same buffer to remove ammonium sulphate. The resulting solution (about $1.5 \mathrm{ml}, 22.4 \mathrm{mg}$ protein $/ \mathrm{ml}$ ) was called Fraction C.

\section{Examination of CLP effects on isolated seminal vesicle secretion fractions}

Fraction A was suspended in 0.15 M-phosphate buffer, pH $7.5(2 \mathrm{mg} / \mathrm{ml})$ and to an aliquot of this suspension, an equal volume of CLP solution was always added. Following incubation for $0.5,1,3$ or $8 \mathrm{hr}$ at $37^{\circ} \mathrm{C}$, the mixture was centrifuged for $20 \mathrm{~min}$ at $1200 \mathrm{~g}$. Proline and nitrogen contents were determined in the clear supernate, and the insoluble residue was analysed by electron microscopy.

Incubation of $0.5 \mathrm{ml}$ Fraction B with $0.5 \mathrm{ml}$ CLP solution was performed at $37^{\circ} \mathrm{C}, \mathrm{pH} \mathrm{7.5}$, for $8 \mathrm{hr}$. Samples of the incubation mixture $(25 \mu \mathrm{l})$ were subjected to disc electrophoresis (Reisfeld, Lewis \& Williams, 1962) at $\mathrm{pH} 8.3$ and $7.5 \%$ acrylamide concentration at the beginning and end of incubation.

Fraction $\mathrm{C}$ was treated in exactly the same way as Fraction B.

Incubations of the three fractions in buffer without CLP were used as controls.

Examination of vesiculase effects on seminal vesicle secretion fractions

To observe the effect of vesiculase on seminal vesicle secretion fractions, an incubation mixture containing $10 \mathrm{mg}$ Fraction A, $6 \mathrm{mg}$ protein of Fraction B and $5 \mathrm{mg}$ protein of Fraction $\mathrm{C}$ was prepared. To this mixture, the total volume of which was $1 \mathrm{ml}, 1 \mathrm{ml}$ vesiculase was added and its effect was observed macroscopically at $21^{\circ} \mathrm{C}, \mathrm{pH} 7 \cdot 5$. The weight ratio of fractions in this incubation mixture was approximately the same as that obtained by the fractionation procedure (60:31.7:26.9 $\mathrm{mg}$ from $1.2 \mathrm{ml}$ seminal vesicle secretion), but their concentration was about ten times lower. The effect of vesiculase was observed in the following combinations: (a) mixture of all three fractions ( $A, B$ and $C$ ) pretreated in buffer at $37^{\circ} \mathrm{C}, \mathrm{pH} 7.5$ for $8 \mathrm{hr}$ (later referred to as intact 
fractions'); (b) mixture of intact Fractions A and B without $\mathrm{C}$; (c) mixture of CLP-pretreated Fraction A and intact Fractions B and C; (d) mixture of intact Fractions A and C and CLP-pretreated Fraction B, (e) mixture of CLP-pretreated Fractions $\mathrm{A}$ and $\mathrm{B}$ and intact Fraction $\mathrm{C}$.

Assays

Proteins were determined by the method of Lowry, Rosebrough, Farr \& Randall (1951) using bovine serum albumin as standard, proline according to the method of Troll \& Lindsey (1955), hydroxyproline according to the method of Prockop \& Udenfriend (1960) and hexosamines by the method of Blix (1948). Nitrogen was estimated by nesslerization after heating the samples in a mixture of sulphuric acid and hydrogen peroxide.

For electron microscopy, a drop of the reaction mixture of Fraction A and CLP taken at the beginning and at the end of incubation were each mixed with a drop of $2 \%$ sodium phosphotungstate on top of a copper grid and immediately examined in a Siemens Elmiskop 1A.

Table 1. Proline, nitrogen and protein contents in the purified insoluble material from rat seminal vesicle secretion

\begin{tabular}{l|l|c|c}
\hline & \multicolumn{1}{|c|}{ Dry weight $(\mu \mathrm{g} / \mathrm{mg})$} & $\begin{array}{c}\text { Insoluble } \\
\text { material }(\%)\end{array}$ & $\begin{array}{c}\text { No. of } \\
\text { estimations }\end{array}$ \\
\hline Proline & $81 \cdot 6^{*}(80 \cdot 0$ to $83 \cdot 2)$ & $8 \cdot 16$ & 4 \\
Nitrogen & $106 \cdot 0(100 \cdot 0$ to $116 \cdot 0)$ & $10 \cdot 6$ & 5 \\
Protein & $620(601$ to 625$)$ & $62 \cdot 0$ & 4 \\
\hline
\end{tabular}

Values are given as means with the ranges in parentheses.

Table 2. Release of proline from the insoluble material in rat seminal vesicle secretion during its incubation with CLP

\begin{tabular}{c|c|c|c}
\hline $\begin{array}{c}\text { Incubation } \\
\text { time (hr) }\end{array}$ & $\begin{array}{c}\mu g \text { Proline released } \\
\text { by CLP action from } \\
1 \text { mg insoluble } \\
\text { material }\end{array}$ & $\begin{array}{c}\text { \%o Total proline } \\
\text { content in } 1 \text { mg } \\
\text { insoluble material }\end{array}$ & $\begin{array}{c}\text { No. of } \\
\text { estimations }\end{array}$ \\
\hline 0.5 & $6 \cdot 3^{*}(5 \cdot 0$ to $7 \cdot 3)$ & $7 \cdot 7$ & 3 \\
1 & $13 \cdot 1(11.6$ to $14 \cdot 2)$ & $16 \cdot 0$ & 3 \\
3 & $15 \cdot 6(15.4$ to $15 \cdot 9)$ & $19 \cdot 1$ & 3 \\
8 & $18 \cdot 1(16.2$ to 19.2$)$ & $22 \cdot 1$ & 4 \\
\hline
\end{tabular}

Values are given as means with the ranges in parentheses.

\section{RESULTS}

Fraction A was a white powder, soluble in $0.05 \mathrm{M}$-acetic acid but insoluble in water, 0.15 M-sodium chloride solution, 0.15 M-phosphate buffer ( $\mathrm{pH} 7.5$ ) or in $0.05 \mathrm{M}$-tris-acetate buffer ( $\mathrm{pH} \mathrm{7.5)}$. In these media, it appeared in the form of a coarse suspension. The proline, nitrogen and protein contents of Fraction A 
are given in Table 1; hydroxyproline and hexosamine were not detected. Fraction A showed a moderate PAS reaction.

After being incubated with CLP for periods up to $8 \mathrm{hr}$, particles in the suspension of Fraction A became smaller, and proline-containing peptides, but no free proline, were released (Table 2). The proline to nitrogen $(w / w)$ ratio was 0.77 in untreated Fraction $\mathrm{A}$ and 1.03 in the peptides released.

Trasylol (700 i.u./ml) did not affect CLP activity, but 50 mм-EDTA completely inhibited the degradation of Fraction A.

Electron microscopy showed that both before (Pl. 1, Fig. 3) and after treatment with urea and acetone Fraction A consisted of spherical structures approximately $300 \mathrm{~nm}$ in diameter. After incubation with CLP, these structures were degraded to fibrillar fragments (Pl. 1, Figs 1 and 2).

Disc electrophoresis at $\mathrm{pH} 8.3$ demonstrated that Fraction $\mathrm{B}$ contained four cathode-migrating (basic) protein fractions which could be readily degraded by CLP (Koren et al., 1974). Fraction $\mathrm{C}$ contained three anode-migrating proteins which could not be degraded by CLP.

Macroscopic inspection of the effect of vesiculase on single fractions revealed the formation of a fine precipitate in the case of Fraction B, while the two other fractions remained unchanged. Addition of vesiculase to a mixture of Fractions $\mathrm{A}, \mathrm{B}$ and $\mathrm{C}$ gave rise, within $20 \mathrm{sec}$, to a compact coagulum very similar in appearance to the copulatory plug (Pl. 1, Fig. 4). The same result was obtained in the absence of Fraction C. If, in such experiments, either A or B had been pretreated with CLP, there was no immediate change when the three components were mixed. After 30 min, however, numerous small coagula were present (Pl. 1, Figs 5 and 6). If Fractions $A$ and $B$ had been pretreated with CLP, no coagula were present after several hours (Pl. 1, Fig. 7).

\section{DISCUSSION}

The fact that vesiculase precipitates the basic protein of rat seminal vesicle

\section{EXPLANATION OF PLATE}

FIG. 1. Electron micrograph of the incubation mixture containing the insoluble material from rat seminal vesicle secretion and collagenase-like peptidase from rat testis at the beginning of incubation at $37^{\circ} \mathrm{C}$, and $\mathrm{pH} 7.5$. Spherical particles of 250 to $350 \mathrm{~nm}$ in diameter are visible. $\times 25,000$.

Fig. 2. Electron micrograph of the incubation mixture containing the insoluble material from rat seminal vesicle secretion and collagenase-like peptidase from rat testis after an 8 -hr incubation at $37^{\circ} \mathrm{C}$, and $\mathrm{pH} 7 \cdot 5$. Fibrillar fragments (40 $\mathrm{nm}$ width) are visible. $\times 25,000$.

Fig. 3. Electron micrograph of the insoluble material from rat seminal vesicle secretion after an 8 -hr incubation at $37^{\circ} \mathrm{C}$ and $\mathrm{pH} 7 \cdot 6$, without collagenase-like peptidase. $\times 25,000$.

Fig. 4. Coagulum formed by the action of vesiculase on the mixture of intact Fractions $A, B$ and C. $\times 50$.

Fig. 5. Coagula formed by the action of vesiculase on the mixture of intact Fraction $A$ and CLP-treated Fraction B. $\times 50$.

FIG. 6. Coagula formed by the action of vesiculase on the mixture of intact Fraction $B$ and CLP-treated Fraction A. $\times 50$.

FIg. 7. Mixture of GLP-treated Fractions A and B $2 \mathrm{hr}$ after addition of vesiculase. Note absence of coagulation. $\times 50$. 
PIL.TIE 1

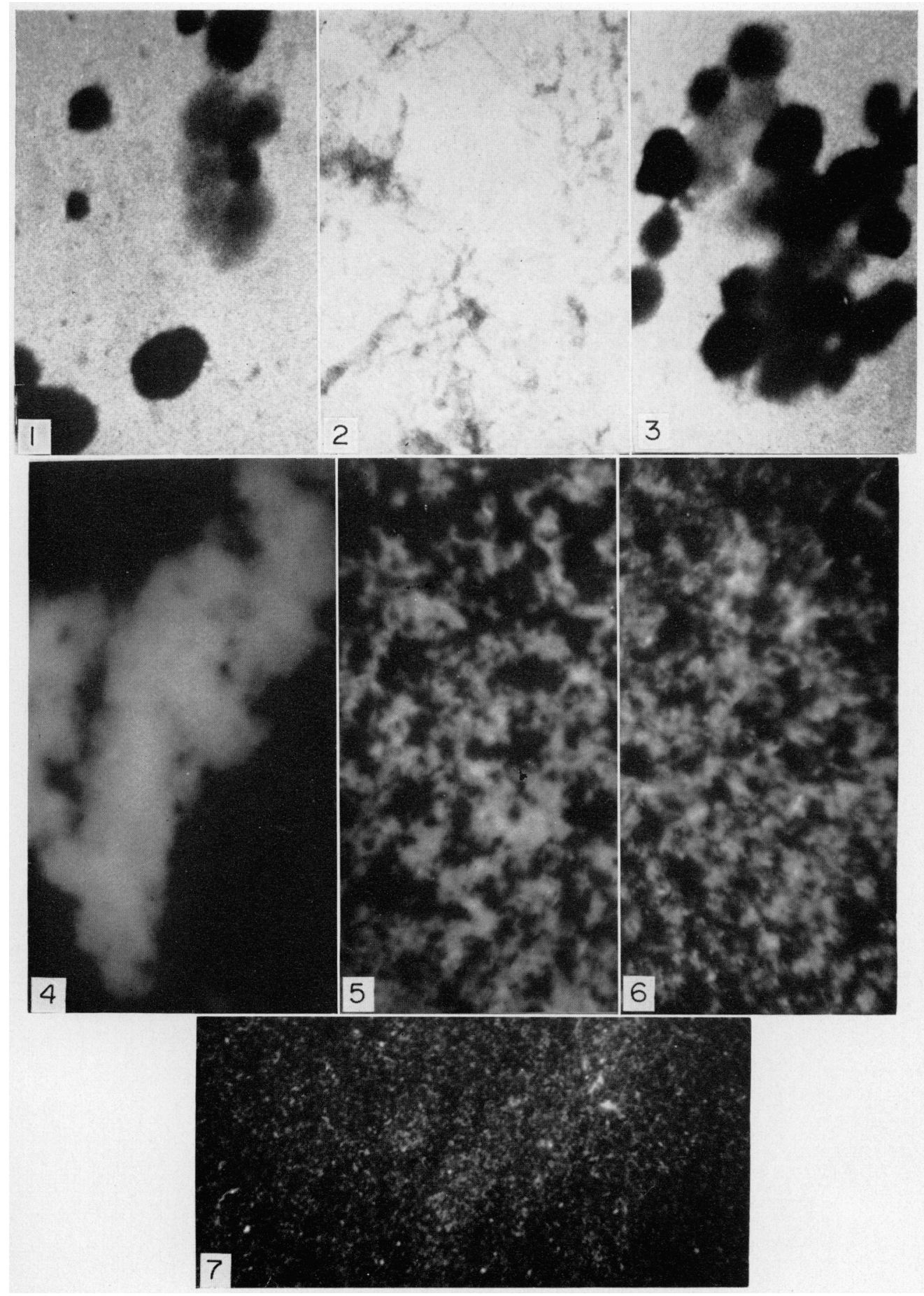

lacing p. +94 
secretion led Manyai (1964) to conclude that basic protein is a component of the copulatory plug. We find that in addition to the basic proteins an insoluble protein (A) is required in order to produce in vitro a coagulum resembling the plug. Neutral or acidic proteins (Fractions G) do not seem to be necessary for the formation of such a coagulum. Analyses and electron micrographs indicate that Fraction A is a macromolecular protein-polysaccharide complex. The action of CLP on Fraction A suggests that proline-rich peptides play a rôle in maintaining the conformation of the spherical structures. Since CLP is a sperm enzyme capable of degrading components of the copulatory plug, it seems reasonable to suppose that this enzyme may assist spermatozoa to escape from the plug post coitum.

\section{ACKNOWLEDGMENTS}

This work was supported in part by research grant No. 720-0440 from the Ford Foundation, New York, N.Y., and grant No. IV/3 from the Croatian Republican Research Fund.

\section{REFERENGES}

BuIx, G. (1948) Acta chem. scand. 2, 467. Quoted by: Gardell, S. (1958) Determinations of hexosamines. In Methods of Biochemical Analysis, vol. 6, pp. 289-300. Ed. G. Glick. Interscience, New York.

Gotterer, G., Ginsberg, D., Schulman, T., Banks, J. \& Wirliams-Ashman, H. G. (1955) Enzymatic coagulation of semen. Nature, Lond. 176, 1209-1211.

Koren, E., Lukað̌, J. \& MrLkovič, S. (1974) The effect of collagenase-like peptidase from rat testis and clostridial collagenase $\mathrm{A}$ on the rat seminal vesicle secretion and its coagulation. $\mathcal{F}$. Reprod. Fert. 36, 161-167.

Koren, E. \& MrLkovič, S. (1973) Collagenase-like peptidase in human, rat and bull spermatozoa. 7. Reprod. Fert. 32, 349-356.

Lowry, O. H., Rosebrough, N. Y., FarR, A. L. \& Randall, R. J. (1951) Protein measurement with the folin phenol reagent. $\mathcal{F}$. biol. Chem. 193, 265-275.

Mann, T. (1954) The two components of semen, spermatozoa and seminal plasma. In The Biochemistry of Semen, pp. 1-32. Eds. Sir Rudolph Peters and F. G. Young, Methuen, London.

MANYAI, S. (1964) Isolation of the clottable protein from the secretion of the rat's seminal vesicle. Acta physiol. hung. 24, 419-432.

Prockop, D. J. \& Udenfriend, S. (1960) A specific method for the analysis of hydroxyproline in tissue and urine. Analyt. Biochem. 1, 228-235.

Reisfeld, R. A., Lewis, V. J. \& Williams, D. E. (1962) Disc electrophoresis of basic proteins and peptides on polyacrylamide gels. Nature, Lond. 195, 281-290.

Troll, W. \& Lindsey, J. (1955) A photometric method for the determination of proline. F. biol. Chem. 215, 655-659. 